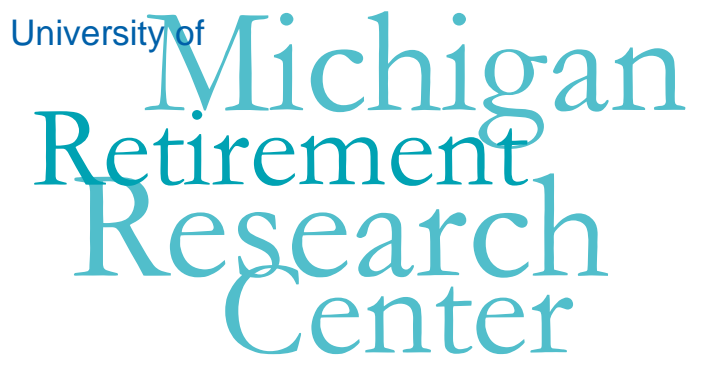

Working Paper WP 2010-257

\title{
Earnings Growth versus Measures of Income and Education for Predicting Mortality
}

\author{
Harriet Orcutt Duleep and David A. Jaegar
}

\begin{tabular}{|l|l|}
\hline $\mathrm{M}$ & $\mathrm{R}$ \\
\hline $\mathrm{R}$ & $\mathrm{C}$ \\
\hline
\end{tabular}

Project \#: UM10-24 



\title{
Earnings Growth versus Measures of Income and Education for Predicting Mortality
}

\author{
Harriet Orcutt Duleep \\ Thomas Jefferson Program in Public Policy, College of William and Mary \\ and IZA- Institute for the Study of Labor
}

David A. Jaeger

City University of New York Graduate Center

and IZA- Institute for the Study of Labor

September 2011

\author{
Michigan Retirement Research Center \\ University of Michigan \\ P.O. Box 1248 \\ Ann Arbor, MI 48104 \\ http://www.mrrc.isr.umich.edu/
}

(734) 615-0422

\section{Acknowledgements}

This work was supported by a grant from the Social Security Administration through the Michigan Retirement Research Center (Grant \# 10-M-98362-5-02). The findings and conclusions expressed are solely those of the author and do not represent the views of the Social Security Administration, any agency of the Federal government, or the Michigan Retirement Research Center.

Regents of the University of Michigan

Julia Donovan Darrow, Ann Arbor; Laurence B. Deitch, Bingham Farms; Denise Ilitch, Bingham Farms; Olivia P. Maynard, Goodrich; Andrea Fischer Newman, Ann Arbor; Andrew C. Richner, Grosse Pointe Park; S. Martin Taylor, Gross Pointe Farms; Katherine E. White, Ann Arbor; Mary Sue Coleman, ex officio 


\title{
Earnings Growth versus Measures of Income and Education for Predicting Mortality*
}

\begin{abstract}
This paper begins an exploration to determine whether earnings growth, as a measure of the propensity to invest in human capital, is a valuable variable for predicting mortality. To insure its robustness and general applicability to ongoing Social Security models, the usefulness of earnings growth as a predictor of mortality will be explored in multiple time periods. This paper begins that process by reporting preliminary results for an early time period using the 1973 CPS-SSA-IRS Exact Match file. In addition to presenting preliminary results, the paper also describes how data challenges associated with the pre-1978 administrative record data on earnings and mortality are met.
\end{abstract}

\section{Authors' Acknowledgements}

*The author would like to thank Linda DelBene, Robert Gesumaria, Hilary Waldron, and especially Patrice Cole for help with this project. Please send any comments to hduleep@wm.edu. 


\title{
Earnings Growth versus Measures of Income and Education for Predicting Mortality
}

\author{
Harriet Orcutt Duleep \\ Thomas Jefferson Program in Public Policy, College of William and Mary \\ and IZA-Institute for the Study of Labor \\ and \\ David A. Jaeger \\ City University of New York Graduate Center \\ and IZA- Institute for the Study of Labor
}

I. Background: Varying Perspectives on the Inverse Relationship Between Mortality and Socioeconomic Status

A strong inverse relationship between mortality and socioeconomic status as measured by income and education has been monitored and analyzed (e.g. Kitagawa and Hauser, 1973;

Waldron, 2007a, b, 2004, 2002). Researchers have also found a pronounced income effecteven after accounting for the deleterious effect of poor health on income - that is greatest at low levels of income and decreases as income rises (e.g., Duleep, 1983, 1986a, b, c; McDonough, Duncan, Williams, and House, 1997).

One school of thought suggests that mortality is a function of levels of schooling and income. Schooling increases health knowledge or the efficiency with which individuals produce health. Income affects health and mortality via the consumption of health-relevant goods and services, such as medical care. Under the belief that different components of socioeconomic status capture different factors that affect health and mortality, researchers estimate the separate effects of income and education on mortality in an effort to understand the underlying causality (e.g. Deaton and Paxton, 1999).

A second school of thought, first promoted by Fuchs $(1975,1982,1983)$ suggests that education, income, and health are all a function of individuals' propensity to invest in human 
capital. For instance, Fuchs argues that education does not affect health behavior but that the

extent to which an individual invests in health and schooling are outcomes of the same process:

\begin{abstract}
...Both schooling and health are manifestations of differences among individuals in the willingness and/or ability to invest in human capital. Both schooling and health-related activities involve incurring current costs for the sake of future benefits, and it seems quite clear that individuals differ in the 'rate of return' that will induce them/or their parents to undertake such investments. (Fuchs, 1979, pp. 159-160).
\end{abstract}

Pondering the policy implications of health and mortality differentials, Fuchs wrote:

In the 1920s, R.H. Tawney, surveying the eighteenth- and nineteenth-century attitudes towards poverty, wrote that 'the most curious feature in the whole discussion... was the resolute refusal to admit that society had any responsibility for the causes of distress.' 1

Some future historian, in reviewing mid-twentieth-century social reform literature, may note an equally curious feature - a 'resolute refusal' to admit that individuals have any responsibility for their own distress. From the idealization of individual responsibility we have gone, in some quarters, to the denial of individual responsibility and the idealization of social responsibility....

In our zeal to raise health levels...we must be wary of impinging on other valuable 'rights' including the right to be left alone. Strict control over a man's behavior might well result in increased life expectancy, but a well-run zoo is still a zoo and not a worthy model for mankind. (Fuchs, 1974, pp. 27, 29).

A third train of thought espoused by Duleep (1986c, 2007) suggests that the socioeconomic differential in mortality primarily reflects variations in individuals' health investment behaviors. And that variations in the propensity to invest in health — and all forms of human capital — reflect rational responses by individuals to their social and economic environments, beginning with childhood and school experiences and continuing with experiences in the labor market. This behavioral investment model posits that the probability of investment in health is a function of the perceived return to investments in human capital in general.

How does an individual assess the probability of a positive return to investing in human capital? Human capital theory and empirical economics generally study investment in human capital as a function of the costs of investment - including opportunity costs (what the time and money could have been used for other than the investment) - and the benefits from investment.

\footnotetext{
${ }^{1}$ The quote is from Tawney (1920, p. 276).
} 
Individuals pursue investments in human capital if the net present value of the stream of lifetime benefits exceeds the associated costs.

It is the perceived expected benefits, however, that affect an individual's decision whether to invest or not. A simple example is the "discouraged worker effect:" whether people search for work is a function of the expectation of finding work. The expectation of finding work is based on individuals' own experiences and the experiences of those around them, resulting in the oftobserved phenomenon of the unemployment rate (defined as the percent unemployed of those actively seeking work) rising with improved economic conditions; as economic conditions improve, people who hadn't bothered to look for a job begin to look. More generally, the discouraged worker effect suggests that people only embark on an activity if they think there is a reasonable chance for the effort to result in success - a perception shaped by their own experiences and the experiences of those around them. ${ }^{2}$

This theory can be applied to the problem of differential preventive health behavior by socioeconomic status. Persons who have experienced a life of unsuccessful outcomes such as dropping out of school and unemployment would be unlikely to undertake preventive health behaviors because of their experience of failure in general.

... whether an individual invests in his health is a function of the perceived likelihood of success accompanying preventive health behaviors. This perception is affected by an individual's experience in society - experience that either fosters or discourages a sense of control — and by the health levels of one's associates. The experience of poverty including an unsuccessful experience with schooling and the job market, and the lower level of health in poor communities, does not foster preventive health behavior.

This theory is similar to the rational expectations theory of behavior in that behaviors are based on expectations formed by what the individual learns from past experience and what he observes around him and may be continuously adapted to changing circumstances. Here it is suggested, however, that outcomes of behavior in one sphere of life generalize to expectations of outcomes of behavior in other spheres.... People invest in their health if they think their actions will be successful, based on their experience in general, and their perception as to the level of health they can attain... (Duleep, 1986c)

Control over one's destiny is another way to think of the nexus linking individual expectations to human capital investment behavior. Whether an individual undertakes actions to

\footnotetext{
${ }^{2}$ Both concepts discussed here have a theoretical basis in the precepts of reinforcement and generalization of behavioral psychology.
} 
maintain and promote health, or to invest in any form of human capital, depends upon the individual's sense of control over his life in general. One's experiences in society affect an individual's sense of control. Coleman (1966) found that a strong predictor of school achievement is the extent to which an individual feels he has control over his destiny. He further found that minority pupils have far less conviction than whites that they can affect their own environments and futures and that an individual student's perception of control strongly correlates with the perception of control possessed by other students in the same school.

Motivation in the behavioral investment model is a mutable quality. The propensity to invest in all forms of human capital is a function of the perceived return to investments in human capital, where this perception is affected by an individual's (and his associates' and even his ancestors') experiences in society. Social and economic policy can affect the propensity to invest in human capital, hence health, by creating social and economic environments that foster a feeling of control in individual lives, where actions to invest in human capital are perceived as having a payoff. Integral to the behavioral investment model is that social and economic policy can affect the propensity to invest in human capital, hence health. Moreover, policy intervention to change social and economic environments in this way is an appropriate goal that liberates rather than shackles individuals.

The second and third frameworks embrace radically different policy perspectives. In the model proposed by Fuchs, individuals make decisions, reflecting their own freely chosen time preferences, as to whether or not to smoke, to exercise, and to invest in schooling and job training. ${ }^{3}$ Accordingly, policy intervention is either impossible or inadvisable. In the model

\footnotetext{
${ }^{3}$ In his seminal work, Grossman (1972) argues that persons demand health as an investment good in which health affects the total amount of time available for market and nonmarket production. Since the wage rate measures the rate at which a person can convert hours of work into money earnings, the higher the wage, the greater the demand for health.
} 
proposed by Duleep, experiences that affect individuals' propensity to invest in human capital, a.k.a. motivation, are amenable to economic and social policy.

Yet, both frameworks acknowledge the important role of individual behavior; both are consistent with mounting empirical evidence of the importance of personal behaviors in determining health and longevity. And, in both frameworks, the key variable determining health and mortality is the propensity to invest in human capital.

Following in these footsteps, this paper begins an exploration to determine whether earnings growth, as a measure of propensity to invest, is a useful variable for predicting mortality in addition to, or instead of, the more commonly used measures of socioeconomic status-levels of income and education.

II. Income and Education as Predictors of Mortality for Social Security Purposes Mortality is a key component of the models that government scholars use to project the financial status of Social Security programs and to simulate the effects of program changes. Since mortality varies profoundly by socioeconomic status, understanding how various measures of socioeconomic status predict mortality contributes to more accurate predictions of mortality. Understanding how mortality varies by socioeconomic status also informs analyses of the progressivity of the system (e.g. Duggan, Greenlees, and Gillingham, 2007).

This paper explores the importance of earnings growth as a predictor of mortality in comparison with the more traditional socioeconomic predictors of mortality-levels of income and education. This type of information can be used in dynamic microsimulation models, which start with a representative sample of the population of interest and simulate socioeconomic behavior 
on a probabilistic basis for each individual according to research linking relevant behaviors to given characteristics.

Social Security microsimulation models, such as the Modeling Income in the Near Term (MINT) model, use survey data matched to Social Security administrative record data on earnings, disability, and mortality. From the survey data, information on individuals' education and income levels is available. From the administrative record data, the earnings histories of individuals help predict future outcomes. ${ }^{4}$

It would also be highly advantageous for SSA to be able to forecast mortality—on an ongoing basis - using only the administrative record data. Since the agency already collects, maintains, and updates these data for administrative purposes, such a model could be continuously and inexpensively updated, ad infinitum.

For Social Security forecasting purposes, variables that can predict mortality many years forward are particularly useful. Education is a key predictor in this regard. However, Social Security's administrative records lack information on education, whereas the administrative data do follow individual earnings. This paper broaches whether earnings growth provides a useful tool to predict mortality many years hence, as an adjunct to education, or by itself in models that rely solely on administrative record data.

To insure its robustness and general applicability to ongoing Social Security models, the usefulness of earnings growth as a predictor of mortality should be explored in multiple time periods. This paper begins that process by reporting preliminary results for an early time period using the 1973 CPS-SSA-IRS Exact Match file. A challenge in using Social Security data for

\footnotetext{
${ }^{4}$ See, for instance the discussion of predicting earnings in Iams and Sandell (1997) or the discussion of predicting immigrant and native earnings in Duleep and Dowhan (2008a, b, c).
} 
various time periods is that the administrative recording of earnings and mortality data changed after 1978, requiring careful thought about how to best use the data.

The next section describes how several data challenges associated with the earlier data are met. Section III also presents a basic model that this paper uses to compare levels of earnings and education with earnings growth as predictors of mortality. Section IV then explores what happens to the estimated effect of earnings on mortality when the period over which earnings are measured lengthens. Section V adds a simple measure of earnings growth to the estimating equation. Section VI examines how well earnings predict mortality when we measure earnings at the beginning of working lives. The paper ends with preliminary conclusions and directions for future research.

\section{The Data and Preliminary Model}

The basic database used for this paper's analyses is the longitudinal 1973 CPS-IRS-SSA Exact Match File. This file combines economic and demographic information on individuals, such as years of schooling and marital status, from the 1973 Current Population Survey (CPS), Internal Revenue Service (IRS) income tax return information and Social Security Administration (SSA) longitudinal annual records on individual earnings, disability, and mortality. Scholars in the Division of Economic Research of Social Security created this file. For information and documentation on the 1973 CPS-IRS-SSA Exact Match File, refer to Aziz, Kilss, and Scheuren (1978) and DelBene (1979).

The administrative record data have several advantages over survey data. The accuracy of certain types of information such as individual incomes likely exceeds corresponding survey data since the administrative information is collected from the individual for whom the 
information pertains and under the force of law. Longitudinal records on earnings, employment, and other items maintained through administrative record keeping systems undoubtedly possess a higher degree of accuracy than historical data based on the memory of survey respondents. The administrative record data — with its historical longitudinal earnings data on individualsmake it possible to explore the importance of earnings levels, averaged over many years, and earnings growth for predicting mortality. A key strength of the administrative record data is that they permit us to examine mortality as it relates to socioeconomic status for multiple time periods.

A drawback of the original Exact Match file for this study's purposes is a severe undercoverage of mortality information for the non-retired population. This problem was overcome by accessing all sources of Social Security death reporting. The accumulated mortality data on the file used for this paper indicate only whether individuals in the CPS sample died during the years 1973-1978. ${ }^{5}$ The resulting dataset permits exploring the effects of earnings growth and levels of schooling and earnings for men 35-64 years of age in 1973 on their subsequent mortality during a six-year period. ${ }^{6}$

\section{A. Insuring accurate use of the Social Security mortality data}

In using Social Security data, an important concern is the quality of the death reporting.

Two studies assess its accuracy for the time period in which mortality is measured in this study.

Aziz and Buckler (1980) compared death rates based on Social Security sources with corresponding rates based on vital statistics data. Their analysis reveals a steady increase in the coverage of Social Security death reporting over time; the improvement reflects an expansion of

\footnotetext{
${ }^{5}$ Year of death information varies some among the various sources of mortality information in the administrative record system. The issue of which source is best is not addressed in this paper. The approach of measuring whether or not a death occurred in the given time interval precludes hazard analysis.

${ }^{6}$ The period over which mortality is measured is actually somewhat short of 6 years. The starting point of the mortality risk period is the March 1973 Current Population Survey. Deaths of survey respondents were searched in all sources of Social Security administrative data up through the records for 1978.
} 
persons covered by Social Security as well as technical improvements in Social Security's record keeping systems. The last year of deaths studied - 1977—found that 98.5 percent of all deaths were recorded in the combined earnings and beneficiary record systems.

DelBene and Aziz (1982) matched a sample of 25,000 death certificates for deaths occurring in 1975 to Social Security records. They found that Social Security death reporting in 1975 was virtually complete for white males 65 years old and over; for white adult males younger than 65 , the coverage rate was about 90 percent. For women and blacks, the death reporting was lower.

The primary reason for the underreporting found in these studies is that the comparisons were done for the general population without regard to whether individuals were eligible for Social Security benefits. Prior to 1978, however, records on mortality were usually maintained only for persons who were in some way covered by Social Security. To insure accurate use of the Social Security mortality data, the study population in this study is limited to white married men who had worked sufficient quarters in covered employment to be eligible for disability benefits. Death reporting for this population should be close to perfect. ${ }^{7}$

\section{B. Dealing with zero earnings}

Prior to 1978, Social Security only recorded and maintained earnings data from Social Security covered employment; the administrative record system recorded zero earnings for persons employed in uncovered employment. This makes it difficult to distinguish the unemployed, or labor force dropouts, from persons fully employed in uncovered employment, or to distinguish the partially employed from persons working in both the covered and uncovered sectors.

In an analysis that used the 1973 CPS-SSA Exact Match File data to estimate the effect of the Civil Rights Act on relative black earnings, Duleep and Regets (1990) limited the sample to

\footnotetext{
${ }^{7}$ The restriction to married men was a further precaution taken to insure the accuracy of the death reporting.
} 
individuals who had positive reported earnings in each of the years of analysis. Waldron (2007a, b), in her analysis with the Social Security administrative record data of trends in mortality differentials by average relative earnings, also excludes zero earners. A drawback of the earnings-in-every-year approach is that no one with unemployment spanning a calendar year will be in the sample.

Waldron (2007a, p. 1) notes:

The sample is expected to be selectively healthier than the general population... This requirement is expected to exclude some of the most at-risk members of the U.S. population because of the strong correlation between labor force participation and health.

In their study of immigrant earnings, Duleep and Dowhan (2002, pp. 490-92) pursued a methodology that permitted examining the sensitivity of their results to the positive earnings restriction.

To examine the earnings growth of immigrant men in the 1960's through 1980's, we first followed for ten-year periods the earnings of working-age foreign- and native-born men... Starting with the most restrictive, we required that men have non-zero earnings in each of the ten years... [In]the least restrictive sample selection rule... instead of a 10-year continuous covered earnings series, positive Social Security earnings are only required for the first and tenth years; breaks in earnings of a year or more due to unemployment, withdrawing from the labor force, leaving covered employment, or returning to the home country are "allowed."

The approach pursued here is to keep in the sample individuals with zero earnings but limit the study population to persons who reported to the CPS employment in occupations and industries that were fully covered by Social Security. ${ }^{8}$ In the same vein, we also excluded from the sample persons who reported to the CPS positive earnings for 1972 but had zero earnings in the Social Security records, suggesting that these individuals were employed in uncovered employment.

Of course, individuals change their employment over time. An individual may have worked in Social Security covered employment in 1972, and worked in uncovered work in some or all of the preceding years. Although measurement error will still be present, the extent of this

\footnotetext{
${ }^{8}$ Classes of workers lacking complete coverage in our period of study include federal civilian employees, state and local government employees, small farmers, domestic workers, and irregularly employed agricultural workers.
} 
problem is greatly reduced in our study. This is because to insure accurate use of the Social Security mortality data, we have limited the sample to those with sufficient quarters in covered work to be eligible for disability benefits: the individuals in our sample have been generally employed in Social Security covered employment.

To gauge the success of this strategy, Table 1 compares the percent of zero earners in each year in the file, for the same demographic group — married white men, 35-64 years oldwith and without our employment-based restrictions. The first column shows the percent with zero earnings with no employment-based restrictions. The second column includes the employment-based restrictions. The third and fourth columns provide national unemployment rates for the civilian labor force and for men who are at least 20 years old.

Prior to 1957, the restricted data do only slightly better than the unrestricted data in tracking unemployment rates for the civilian labor force. Yet, starting in 1957, the percent zero earners in our restricted data set closely track the national rates. ${ }^{9}$

The comparison in Table 1 suggests that the Social Security earnings data for the restricted group is meaningful starting in 1957, meaningful in the sense that if zero earnings are recorded for an individual in any given year, it is likely that that person was not working. With these comparisons in mind, the analyses that follow do not use earnings data for years prior to 1957.

\section{Estimating earnings above the taxable maximum}

\footnotetext{
${ }^{9}$ Indeed, the percent zero earners for the restricted set is lower in almost every year than the national rate, which is not surprising given that the study sample is limited to white married men.
} 
Prior to 1978 , Social Security recorded earnings only up to the maximum amount subject to Social Security taxes. Researchers have pursued various strategies to sidestep the top-coding handicap in the pre-1978 administrative record data.

In an early effort aimed at measuring the effect of the 1964 Civil Rights Act on relative black earnings, Duleep and Regets used maximum likelihood estimation of the Tobit model to compare the mean earnings of whites and blacks before and after the Civil Rights Act. Yet, when they compared white mean earnings estimated with the Tobit model using the censored data with white mean earnings based on uncensored data they discovered that the tobit estimates were substantially off for years when a majority of white earnings are censored. Furthermore, changes in the Social Security ceiling coincided with the timing of the Civil Rights Act, creating a spurious exaggeration of the post-1964 relative effect using tobit estimates of the white means.

Waldron (2007a, b) also used tobit estimation in her study of trends in mortality differentials by average relative earnings. She notes that "although a tobit regression requires a normality assumption and the earnings are not distributed normally, results are unlikely to be affected by use of the tobit, because the earnings are measured in relative terms...."10

Given their experience with tobit estimates yielding misleading results, Duleep and Regets developed another methodology to sidestep the top-coding handicap. Continuing their study of how blacks fared before and after the 1964 Civil Rights Act, Duleep and Regets (1990) estimated the probability of a minority individual earning more than the second decile of earnings for non-Hispanic whites. In a similar study, Card and Krueger (1993) also used this methodology to sidestep the top-coding handicap.

\footnotetext{
${ }^{10}$ The Appendix of Waldron (2004) explores this issue.
} 
In yet another approach, Duleep (1986a) related mortality to Social Security earnings data that was measured in three categories, with the reference category (the fourth category) being individuals with earnings at or above the taxable maximum in 1972 . The strategy was appropriate since analysis with (less constrained) IRS and CPS data showed no significant income effect on mortality beyond the first three income categories.

Nevertheless, for the current research, with its focus on earnings growth, the taxable maximum for the pre-1978 earnings data does pose a crucial constraint. We thus exploited another source of Social Security administrative data to estimate the total earnings for individuals with earnings recorded at the taxable maximum.

Prior to 1978, individuals' earnings were reported to Social Security on a quarterly basis. Using the quarter a person reached the Social Security taxable maximum, total earnings can be estimated as the midpoint between the least he could have earned and the most he could have earned. ${ }^{11}$ That is, if the person reached the taxable maximum (TM) in the third quarter, one can say that he earned at least TM/3 $\times 4$ and at most $(\mathrm{TM}-\$ 50) / 2 \times 4$. (A quarter is recorded if $\$ 50$ or more were earned. $)^{12}$ The average of the minimum and maximum provides an estimate of total earnings.

\section{Efforts to detect ramifications of our sample restrictions and earnings estimates}

\footnotetext{
${ }^{11}$ Although this information is only available until 1978, when the Social Security system started to use annual tax return data, it provides actual data on above-taxable-maximum earnings for the early years when the taxable maximum is most restrictive: prior to 1978, the ratio of each year's taxable maximum to the corresponding year's median wage or salary income of men ranged from 1.00 to 1.57; after 1978, the taxable maximum/median earnings ratio steadily increases from 1.79 to 2.53, in 1993 (Social Security Administration, 1998; U.S. Bureau of the Census, 1998; Economic Report of the President, 1999).

${ }^{12}$ More specifically, a ' $\mathrm{C}$ ' is recorded on the administrative records for the pre-1978 data if the person earned at least $\$ 50$ in that quarter. Prior to 1979 , once a person reached the taxable maximum, no more quarters of coverage were recorded for that year. The first step then is to count the number of C's per year. So, if someone earns at the taxable maximum for a given year, and they have 4 quarters of coverage reported as ' $\mathrm{CCCC}$ ' this means that they earned at least $\$ 50$ in the fourth quarter.
} 
The steps we have described thus far to insure that the data we use are meaningful may diminish the relevance of our results. A goal of this work is to compare earnings growth versus earnings for predicting mortality. If the data steps we have taken substantially reduce the estimated effect of earnings on mortality, then our comparison with earnings growth will be less relevant.

To shed light on this concern, we estimate a mortality model for married white men, 3564 in 1973, first on our restricted sample with the estimated total earnings for 1972 from the administrative record data, then on the same restricted sample, but with the CPS earnings reported for 1972.

The model we estimate is:

$$
\mathrm{P}(\mathrm{D})_{\mathrm{i}, \mathrm{t}}=\beta_{1} \mathrm{Y}_{\mathrm{i}, \mathrm{t}-1}+\beta_{2} \mathrm{Ed}_{\mathrm{i}}+\beta_{3} 1 /\left(66-\mathrm{Age}_{\mathrm{i}}\right)
$$

Where

$\mathrm{P}(\mathrm{D})_{\mathrm{i}, \mathrm{t}}=$ the probability of death for the $i$ th individual, with mortality risk measured from 1973 through 1978.

$\mathrm{Ed}_{\mathrm{i}}=$ a set of dummy variables representing four categories of schooling: 0-8 years, 9-11 years, high school graduation, and 1-3 years of college. Four or more years of college serves as a reference variable.

$\mathrm{Age}_{\mathrm{i}}=$ the age of the individual as measured in March 1973.

To model the relationship between age and probability of death, we use the function $1 /(66-$ Age) in a linear probability model. This function is characterized by a slowly increasing probability of death over much of the 35-64 age range, but with a large increase as one approaches age 64 . 
The estimated coefficients for this model, estimated by ordinary least squares, are shown in Table $2 .^{13}$

The parameters in all three columns of Table 2 are from estimating the model on a sample of white married men who were 35-64 years old in 1973. The sample for the first two columns is further limited to white married men employed in Social Security covered employment with sufficient quarters in that work to be eligible for disability benefits - the employment-based restrictions that define our study sample. The first column shows the estimated model coefficients when the Social Security earnings are used; the second column shows the model coefficients when CPS earnings are used.

The estimated effects of schooling and age in the first two columns are very similar. This is not surprising given that the only difference between the two estimations is the information used to measure earnings. ${ }^{14}$ The key question is whether there is less of a negative relationship between earnings and mortality when we use the Social Security earnings data.

As is shown, the inverse relationship is stronger (the estimated coefficient on earnings more negative) using the Social Security data than the CPS data for the same group of individuals. For instance, according to the first column's coefficients that use the Social Security earnings data, the probability of death over six years is .0867 for a high-school graduate who is 50 years old in 1973 and earned \$20,000 in 1972 versus .1044 for his age and schooling

\footnotetext{
${ }^{13}$ There are problems with OLS estimation of a linear probability model such as this one. Predicted values may go outside the $0-1$ range. (Note however, that if one uses only categories of the explanatory variables, as is done for the schooling levels here, then the problem of predicted values going outside the 0-1 range is solved.) Also, the error term is heteroscedastic. Implicit in the logistic function, which underlies logit analysis, or the cumulative normal distribution used in probit analysis, is an increasing effect of a given explanatory variable until the probability of the event in question is .5. For this reason, the probit and logit models, so commonly used in mortality analyses, may not be the best choice for modeling the effect of socioeconomic status on probability of death. Further analysis of these and other questions related to the basic model and its estimation will accompany the ongoing study of the effect of earnings growth on mortality.

${ }^{14}$ Changes could occur to the extent that when we change how earnings are measured, education and age pick up more or less of the (formerly) earnings' effects.
} 
statistical twin who earned $\$ 10,000$ in 1972 ; the $\$ 10,000$ earnings increase decreases probability of death by about 20 percent. Using the CPS earnings data the comparable estimates are .0837 for the higher earner versus .0975 for the lower earner; the $\$ 10,000$ earnings increase decreases probability of death by about 16 percent.

Another concern is whether, given our sample restrictions, our results on using earnings growth versus earnings are relevant to the broader population, even within the demographically constrained set of white married men. Again, this would be of particular concern if the relationship between earnings and mortality estimated on the employment-constrained sample were substantially less than the relationship estimated on data sans the employment-based restrictions.

When we do estimate the model with CPS earnings on the Exact Match File sample, but without imposing the covered employment restrictions, the estimated effect of earnings on mortality is much lower, and the coefficients on schooling are lower as well (third column, Table 2). The weaker effects of earnings and schooling, however, are likely due to an undercoverage of death reporting when the covered employment restrictions are not imposed. As such, this analysis leaves this aspect of how generalizable the results are unresolved.

Before proceeding to the comparisons of the mortality effects of earnings and earnings growth, let us take a closer look at the coefficients on schooling. If education affects mortality by improving health knowledge, or increasing the efficiency with which individuals produce health, then we would expect that the relationship between years of schooling and mortality would be monotonic: higher levels of education should always be associated with mortality that 
is lower than or equal to the mortality associated with lower levels of education. Yet, the estimated relationship is nonmonotonic. ${ }^{15}$

\section{Lengthening the Period over which Earnings are Measured}

If income affects mortality through its effect on the consumption of health-relevant goods and services, we would expect that permanent income would better predict mortality than transient income measured for only a few years preceding the measurement of mortality risk. If, however, it is the propensity to invest in human capital that is crucial, then as earlier and earlier years of earnings are incorporated into the income measure, its effect on mortality should decrease.

Earnings levels are the fruit of human capital investment. As one goes back in time, to the beginning of people's careers, earnings levels reflect less and less the differences among individuals in their propensity to invest in human capital. Earnings trajectories diverge with age because to the extent that human capital investment occurs, it is most prominent at the beginning of individuals' working lives and decreases as people age. During the first years following schooling completion, persons who are investing in training or are in jobs with growth potential may earn on a par, or even below, individuals who are less engaged in human capital investment. Thus levels of earnings, measured at older ages, capture differences among individuals in their prior propensity to invest better than do earnings measured at younger ages.

Consistent with the traditionally perceived role of income in affecting mortality, Duleep (1986a) found that income averaged over several years correlated more with individuals' ensuing mortality than income measured over a single year. Yet, the increase in the estimated coefficients could have been due to a decrease in measurement error of the income variable. If this were the

\footnotetext{
${ }^{15}$ Also see Duleep (1986a), Panis and Lilliard (1996), and Burtless (1987) on this point.
} 
case, and if it is propensity to invest which is critical, then we would expect an initial increase in income's effect as more years of earnings are averaged into the income measure, followed by a decrease in income's effect as earnings from increasingly younger ages are averaged in.

The first row of Table 3 shows the estimated effects of earnings from the mortality model introduced in Table 2. The left-most result is the estimated earnings effect when earnings are measured only in 1972, when sample individuals who were 35-64 in 1973 are 34-63. The rightmost result is the estimated mortality effect of earnings averaged over the years 1963-1972, when our sample individuals are 25-54.

The effect of the income variable first increases as we go from measuring earnings only in 1972 to measuring earnings over a three-year period. Beyond that, income's effect decreases as the earnings of individuals at earlier ages are averaged in, a result consistent with the propensity to invest hypothesis.

Other explanations come to mind, however. It may be that having income when one is in ill health or injured increases survival. Income at the onset of illness or injury enables individuals to seek good medical care and to leave work for care and recuperation. Hence, income's effect could be highest right before probability of death is measured, and then decrease as we distance it in time from the measurement of mortality risk.

The decreasing effect of income may also reflect a diminution in reverse causality as earnings that are further removed in time from the measurement of mortality risk are incorporated into the permanent income measure. Reverse causality occurs because the behavior of persons and their situations change with their health status. Ill health may cause individuals to change their job, to stop working, or to work less. When we relate earnings measured at one 
point in time to health or mortality we do not know to what extent the relationship reflects the effect of earnings on mortality or the reverse effect of health on the earnings.

Both of these issues can be dealt with by controlling for health conditions prior to and concurrent with the measurement of earnings. The Social Security administrative data provide an annual record of the onset of disability that prevents gainful employment. The 1973 CPS asks respondents whether ill health was the reason for no work or part-time work in 1972. To control for health problems that may have affected income, a dummy variable is included in the mortality model that equals 1 if the person was ever recorded as disabled on the Social Security records prior to or concurrent with the earnings used in the estimation or if the individual reported on the Current Population Survey that health prohibited or limited work. This disability variable is also interacted with age.

The second row of results in Table 3 shows the estimated earnings effect on mortality controlling for the presence of disabling conditions that affect the ability to earn. Comparing the income coefficients of the first and second rows, we see that the estimated adverse effect on mortality associated with low income decreases when health problems that may have affected income are controlled for, thereby providing evidence that some of the negative incomemortality association is due to the effect of poor health on income. Nevertheless, a pronounced income effect persists, replicating earlier results on this issue. ${ }^{16}$

Yet, the pattern that interests us in this research remains: income's effect first increases, and then decreases as earlier years of earnings are averaged in.

\footnotetext{
${ }^{16}$ Other studies that have dealt with the reverse causality problem by explicitly taking into account health status include Duleep (1983, 1986a, b, c), Zick and Smith (1991), Wolfson, Rowe, Gentleman, and Tomiak (1993), and Smith and Zick (1994) and McDonough, Duncan, Williams, and House (1997).
} 


\section{Adding a Simple Measure of Earnings Growth}

If propensity to invest in human capital is the critical determinant of health and mortality, as opposed to level of income, then we would expect that earnings growth, measured over the entire career of individuals would supersede income's effect as a predictor of mortality. Although income is an indicator of the extent to which individuals have invested in human capital, earnings averaged over the work cycle will not necessarily distinguish among persons who varied in the extent to which they invested in human capital. Individuals with the same average earnings who start with very low earnings, but experience high rates of human capital investment would not be distinguished from individuals whose earnings are higher initially but experience very little earnings growth. Yet, according to the propensity to invest perspective, the former will have lower mortality.

Table 4 tests this hypothesis. In the first column, we estimate the mortality model using earnings averaged over a ten-year period. Following that, we add to the model earnings growth, measured as the simple difference between an individual's earnings in 1972 and their earnings in 1963. The second column measures this difference in constant dollars; the third column measures the difference in nominal dollars.

Including earnings growth measured in constant dollars to the estimation dramatically reduces the estimated effect of average earnings. When we add earnings growth measured in nominal dollars to the model, the estimated effect of averaged earnings becomes statistically insignificant.

The estimated coefficients on years of schooling are stable regardless of whether or how earnings growth is included in the estimation. Within the propensity to invest perspective, there are two ways to look at the fact that both schooling and earnings growth have important effects 
on mortality. In the framework espoused by Fuchs, the person who has low levels of schooling but high earnings growth is more motivated than the individual who has low levels of schooling and earnings growth, with the difference in motivation being endogenously determined.

According to the model proposed by Duleep, the poorly educated who have positive experiences in the labor market will be more likely to invest in human capital, including health, than the poorly educated who have had unsuccessful experiences in the labor market, with the difference in propensity to invest being exogenously determined.

VI. Earnings as a Predictor of Mortality When Measured at the Beginning of Working Lives. The explorations up to now have used earnings measured up through 1972, the year before mortality risk is measured. For Social Security forecasting purposes, it would be useful to have a predictor, measured in the early years of individuals' working lives that would project future mortality several years hence. Table 5 shows that the earnings of persons when they are 25-34 have no statistically significant effect on mortality ten years hence.

The insignificant earnings' effect arises in part because we are estimating the effect of earnings on the mortality of persons who are 35 to 45 , instead of persons who are 35-64. Antonovsky (1967, p.68) hypothesized that “....when mortality rates are extremely high or extremely low, class differences will tend to be small. In other words, when men are quite helpless before the threat of death, or when men have made great achievements in dealing with this threat, life chances will tend to be equitably distributed. On the other hand, when there is moderate progress in dealing with this threat, differential consequences are to be expected. The crucial idea that may be involved here is that of preventable deaths..." 
With respect to life-cycle variations in the socioeconomic mortality differential, it is likely that, for the ages where death rates are extremely low, people tend to live regardless of the degree of inequity in life-enhancing factors. For the ages where death rates are extremely high, it is likely that people tend to die regardless of the degree of inequity in life-enhancing factors. Socioeconomic mortality differentials are greatest between these two extremes. Consistent with this line of thought, the schooling coefficients shown in Table 5 are smaller than the estimated schooling effects in the estimations shown in Tables 2 and 4. Nevertheless, the schooling coefficients, though smaller in magnitude from the estimations for persons 35-64, still provide valuable predictive information.

Since earnings growth is a sign that individuals are investing in human capital - that they perceive high expected returns to human capital investment, including health — earnings growth may be a better predictor of mortality for individuals following schooling completion, than would income, particularly for individuals who are at the beginning of their working lives. This turns out to be the case, as shown in the bottom half of Table 5.

\section{Concluding Remarks}

This paper is a preliminary effort to assess the value of earnings growth for predicting mortality.

It is important to stress that the explorations presented in this paper are preliminary. We have found a set of results from one time period. The functional form and estimation method used in this paper provide easy-to-interpret estimates and enable comparisons with prior research. However, the results may be sensitive to functional form, the estimation method, and even for corrections of statistical issues with the current estimation. Of particular concern, prior 
work of Duleep (1986a, b) and McDonough, Duncan, Williams, and House (1997) show that income's effect on mortality is nonlinear with the effect greatest at below average levels of earnings. Future explorations will incorporate nonlinearity into the estimation of both the earnings and earnings growth variables.

Keeping these and other caveats in mind, several preliminary conclusions are of interest. The results suggest that both education and earnings growth are useful for predicting mortality. When measured in constant dollars, income mobility has a relationship to mortality separate from income (level) effects. When measured in nominal dollars, the mortality effect of earnings growth supersedes that of income. The results further suggest that earnings growth may be particularly useful when predicting mortality from early working years. If confirmed, this result would be of particular use in forecasting models that rely only on the administrative record data since these data lack information on years of schooling.

Building on this initial foray, we will pursue several issues in future work.

The current effort uses a simple difference to measure earnings growth. Subsequent work will also measure earnings growth with regressions on the individual data, which uses more of the data than the simple difference between two points and may be less subject to measurement error.

Future work will lengthen the time over which mortality is measured. This will permit us to explore further to what extent earnings growth measured at the beginning of the working career viably predicts subsequent mortality. The current analysis uses earnings growth measured at ages 25-34 to predict mortality ten years hence. By updating the mortality information on the 
file, we will learn how earnings growth measured at ages $25-34$ predicts mortality beyond the ten-year horizon presented in this paper. ${ }^{17}$

Other analyses that will inform modeling issues may also shed some light on the underlying causal routes discussed in the beginning background section of this paper. For instance, controlling for earnings growth measured at the beginning of the working life, does earnings growth measured at later ages exert an effect on mortality?

Finally, by using more recent matched survey-administrative data, we will test the importance of earnings growth for predicting mortality in multiple time periods and hence test its robustness as a predictor of mortality.

In conclusion: the building blocks are in place for further analysis; the results, though preliminary, warrant further work. In lawyer's parlance, we are at the indictment stage, with enough evidence to proceed.

\footnotetext{
${ }^{17}$ The observant reader may be wondering why we didn't do this with the current file by going backwards in time to measure the earnings of individuals at the beginning of their working careers. However, this would have necessitated using earnings measured before 1957. For instance, in the current analysis, we examined how the mortality of persons who were 35-44 in 1973 was related to their earnings growth at the beginnings of their careers, in 1963 when these individuals were 25-34. However, individuals who were 45-54 in 1973 would have been 25-34 in 1953, in years before earnings could be meaningfully measured.
} 


\section{References}

Antonovsky, Aaron, “Social Class, Life Expectancy and Overall Mortality,” The Milbank Memorial Fund Quarterly, vol. 45, April, 1967, pp. 31-73.

Aziz, Faye and Warren Buckler, "The Status of Death Information in Social Security Files," 1992 Joint Statistical Association, August, 1992.

Aziz, Faye, Beth Kilss, and Fritz Scheuren, 1973 Current Population SurveyAdministrative Record Exact Match File Codebook, Report no. 8 of Studies from Interagency Data Linkages, U.S. Social Security Administration, Office of Research and Statistics. Washington, D.C.: Government Printing Office, 1978.

Aziz, Faye, Harriet Orcutt, and Linda DelBene, "Social Security Data Files as a Resource for Health Research," 1981 American Statistical Association Proceedings. Reprinted in Statistics of Income and Related Administrative Record Research, Dept. of the Treasury, GPO, 1981.

Burtless, Gary, "Occupational Effects on the Health and Work Capacity of Older Men," in Work, Health, and Income Among the Elderly, ed. Gary Burtless, Washington, D.C.:The Brookings Institution, 1987, pp. 103-142.

Card, David and Alan Krueger, "Trends in Relative Black-White Earnings Revisited." American Economic Review Papers and Proceedings, 83, May 1993.

Coleman, James S. et al., Equality of Education Opportunity, Washington, DC, U.S. Government Printing Office, 1966.

Deaton, Angus and Christina Paxton. "Mortality, Education, Income and Inequality among American Cohorts." NBER Working Paper 7140, National Bureau of Economic Research, Inc, 1999.

DelBene, Linda, 1937-1976 Social Security Longitudinal Earnings Exact Match File, Report no. 9 of Studies from Interagency Data Linkages, U.S. Social Security Administration, Office of Research and Statistics. Washington, D.C.: Government Printing Office, 1979.

DelBene, Linda and Faye Aziz, "Mortality Coverage in Social Security's Earnings and Benefit Record Systems," 1980 Proceedings of the Survey Research Methods Section, American Statistical Association, 1980.

Duggan, James E., John S. Greenlees, and Robert Gillingham, 2007. "Mortality and Lifetime Income: Evidence from U.S. Social Security Records,” IMF Working Papers 07/15, International Monetary Fund, 2007.

Duleep, Harriet Orcutt (2007) "Socioeconomic Determinants of Mortality and the Propensity to Invest," Russell Sage/UCLA Conference on Social Dimensions of Inequality, 2007. 
—, "Measuring the Effect of Income on Adult Mortality Using Longitudinal Administrative Record Data," Journal of Human Resources, Spring, 1986a, pp. 238-251.

—, "Incorporating Longitudinal Aspects into Mortality Research Using Social Security Administrative Record Data," Journal of Economic and Social Measurement, Winter, 1986b. M.I.T. 1986c.

—, Poverty and Inequality in Mortality, Doctoral Dissertation, Dept. of Economics,

—, "The Socioeconomic Determinants of Mortality: The Role of Income," paper presented at the Annual Meeting of the American Economic Association, 1983.

Duleep, Harriet and Daniel Dowhan, "Research on Immigrant Earnings," Social Security Bulletin, vol. 68, no.1, 2008a, pp. 31-50.

—,"Adding Immigrants to Microsimulation Models," Social Security Bulletin, vol. 68, No. 1, 2008b, pp. 51-66.

—, "Incorporating Immigrant Flows into Microsimulation Models," Social Security Bulletin, vol. 68, no.1, 2008c, pp. 67-76.

-, "Insights from Longitudinal Data on the Earnings Growth of U.S. Foreign-born Men," Demography, August, 2002.

Duleep, Harriet Orcutt and Regets, Mark C., "The Relative Earnings of Black Men: Evidence from Longitudinal Earnings Data," paper presented at the annual meeting of the American Economic Association, 1990.

Economic Report of the President February 1999. Washington: Government Printing Office, 1999.

Fuchs, Victor, R., Who Shall Live? Health, Economics, and Social Choice, NY: Basic Books, 1975.

—, "Economics, Health and Post-Industrial Society," Milbank Memorial Fund Quarterly/Health and Society, vol. 57, no. 2, Spring 1979, pp. 153-182.

-, "Time Preference and Health: An Exploratory Study," in V. R. Fuchs, ed., Economic Aspects of Health, Chicago: University of Chicago Press, 1982, pp. 93-120.

-, How We Live: An Economic Perspective on Americans from Birth to Death, Cambridge, Mass. and London, England: Harvard University Press, 1983

Grossman, Michael, The Demand for Health: A Theoretical and Empirical Investigation, New York, Columbia University Press, 1972.

Iams, Howard M. and Steven H. Sandell, "Projecting Social Security Earnings: Past is Prologue," Social Security Bulletin, vol. 60, No.2, 1997, pp. 3-16.

Kitagawa, Evelyn M. and Philip M. Hauser, Differential Mortality in the United States: A Study in Socioeconomic Epidemiology, Cambridge: Harvard University Press, 1973.

McDonough, Peggy, Greg J. Duncan, David Williams, and James House, "Income Dynamics and Adult Mortality in the United States, 1972 through 1989," American Journal of Public Health, Vol. 87, No. 9, September 1997, pp. 1476-1483. 
Panis, Constantijn and Lilliard, Lee, "Socioeconomic Differentials in the Returns to Social Security," Papers 96-05, RAND - Labor and Population Program, 1996.

Smith, Ken R. and Cathleen D. Zick, "Linked Lives, Dependent Demise? Survival Analysis of Husbands and Wives," Demography, vol. 31, no. 1, February 1994, pp. 81-94.

Social Security Administration, Annual Statistical Supplement, 1998, Washington, DC: Social Security Administration, 1998 1920.

Tawney, Richard H. Religion and the Rise of Capitalism, New York, Harcourt Brace,

U.S. Bureau of the Census, Current Population Reports, P60-203, Measuring 50 Years of Economic Change Using the March Current Population Survey, U.S. Government Printing Office, Washington, DC, 1998.

Waldron, Hilary, "Trends in Mortality Differentials and Life Expectancy for Male Social Security-Covered Workers, by Average Relative Earnings," ORES Working Paper No. 108 October $2007 \mathrm{a}$

- "Trends in Mortality Differentials and Life Expectancy for Male Social SecurityCovered Workers, by Socioeconomic Status," Social Security Bulletin, Vol. 67, No.3, 2007 .

—, "Literature Review of Long-Term Mortality Projections," Social Security Bulletin, Vol.66, No. 1. 2005.

-, "Heterogeneity in Health and Mortality Risk Among Early Retiree Men," ORES Working Paper No. 105, Washington, DC: Office of Research, Evaluation and Statistics, SSA, May 2004.

—, "Mortality Differences by Race," ORES Working Paper No. 99, Washington, DC: Office of Research, Evaluation and Statistics, SSA, December 2002.

Wolfson, Michael, Geoff Rowe, Jane F. Gentleman, and Monica Tomiak, "Career Earnings and Death: A Longitudinal Analysis of Older Canadian Men," Journal of Gerontology: Social Sciences, vol. 48, no. 4, July 1993, S167-S179.

Zick, Cathleen D. and Ken R. Smith, "Marital Transitions, Poverty, and Gender Differences in Mortality," Journal of Marriage and the Family, vol. 53, 1991, pp. 327-36. 


\begin{tabular}{|c|c|c|c|c|}
\hline \multirow{2}{*}{ Year } & \multicolumn{2}{|c|}{$\begin{array}{l}\text { Earnings records, percent zero } \\
\text { earners, married white men, 35-64 } \\
\text { years old }\end{array}$} & \multicolumn{2}{|c|}{$\begin{array}{l}\text { Unemployment rate, civilian labor } \\
\text { force (percent) }{ }^{\mathrm{a}}\end{array}$} \\
\hline & unrestricted & restricted & $\begin{array}{l}16 \text { years and } \\
\text { older men and } \\
\text { women }\end{array}$ & Men $20+$ \\
\hline 1951 & 33.14 & 26.08 & 3.3 & - \\
\hline 1952 & 30.27 & 22.88 & 3.0 & - \\
\hline 1953 & 27.68 & 19.96 & 2.9 & - \\
\hline 1954 & 27.62 & 19.40 & 5.5 & - \\
\hline 1955 & 20.31 & 14.18 & 4.4 & - \\
\hline 1956 & 17.69 & 11.59 & 4.1 & - \\
\hline 1957 & 10.90 & 4.65 & 4.3 & - \\
\hline 1958 & 11.26 & 4.76 & 6.8 & - \\
\hline 1959 & 10.79 & 4.00 & 5.5 & - \\
\hline 1960 & 10.98 & 3.91 & 5.5 & - \\
\hline 1961 & 11.33 & 3.67 & 6.7 & - \\
\hline 1962 & 11.25 & 3.51 & 5.5 & - \\
\hline 1963 & 11.54 & 3.21 & 5.7 & - \\
\hline 1964 & 11.62 & 3.18 & 5.2 & 3.9 \\
\hline 1965 & 11.19 & 2.52 & 4.5 & 3.2 \\
\hline 1966 & 10.91 & 2.13 & 3.8 & 2.5 \\
\hline 1967 & 11.28 & 2.08 & 3.8 & 2.3 \\
\hline 1968 & 11.28 & 2.01 & 3.6 & 2.2 \\
\hline 1969 & 11.45 & 2.46 & 3.5 & 2.1 \\
\hline 1970 & 12.36 & 3.29 & 4.9 & 3.5 \\
\hline 1971 & 13.54 & 4.19 & 5.9 & 4.4 \\
\hline 1972 & 14.23 & 5.30 & 5.6 & 4.0 \\
\hline
\end{tabular}




\begin{tabular}{|c|c|c|c|}
\hline Explanatory variables & $\begin{array}{l}1972 \text { SSA earnings, } \\
\text { restricted sample }\end{array}$ & $\begin{array}{l}1972 \text { CPS earnings, } \\
\text { restricted sample }\end{array}$ & $\begin{array}{l}1972 \text { CPS earnings, } \\
\text { unrestricted sample }\end{array}$ \\
\hline 1972 Earnings & $-1.77 \times 10^{6}(5.26)$ & $-1.48 \times 10^{6}$ & $-9.80 \times 10^{7}(4.38)$ \\
\hline \multicolumn{4}{|l|}{$\begin{array}{l}\text { Schooling (Schooling } \\
\text { effects are measured } \\
\text { relative to four or more } \\
\text { years of college) }\end{array}$} \\
\hline $0-8$ years & $0.05124(7.17)$ & 0.05086 & $0.04513(8.03)$ \\
\hline $9-11$ years & $0.05944(8.11)$ & 0.05936 & $0.05105(8.69)$ \\
\hline High school graduation & $0.03145(5.40)$ & $\begin{array}{ll}0.03127 & 5.41 \\
\end{array}$ & $0.02529(5.65)$ \\
\hline $1-3$ years of college & $0.05286(6.04)$ & 0.05364 & $0.04347(6.37)$ \\
\hline $\begin{array}{l}\text { Age in } 1973, \text { measured } \\
\text { as } 1 /(66-\text { Age })\end{array}$ & $0.60133(20.70)$ & $0.60194(20.72)$ & $0.56649(24.88)$ \\
\hline Adjusted $\mathrm{R}^{2}$ & 0.1259 & 0.1260 & 0.1164 \\
\hline Number of observations & 9,618 & 9,618 & 14,778 \\
\hline
\end{tabular}




\begin{tabular}{|c|c|c|c|c|}
\hline & \multirow[t]{2}{*}{$\begin{array}{l}\text { Earnings } \\
\text { measured in } 1972\end{array}$} & \multicolumn{3}{|c|}{ Earnings averaged over the years... } \\
\hline & & 1970-1972 & 1969-1972 & 1963-1972 \\
\hline $\begin{array}{l}\text { Earnings' effect } \\
\text { not controlling for } \\
\text { disability }\end{array}$ & $-1.77 \times 10^{6}(5.26)$ & $-1.88 \times 10^{6}(5.05)$ & $-1.82 \times 10^{6}(4.82)$ & $-1.71 \times 10^{6}(3.92)$ \\
\hline $\begin{array}{l}\text { Earnings' effect } \\
\text { controlling for } \\
\text { disability }\end{array}$ & $-1.17 \times 10^{6}(3.38)$ & $-1.32 \times 10^{6}(3.34)$ & $-1.30 \times 10^{6}(3.34)$ & $-1.27 \times 10^{6}(2.85)$ \\
\hline $\begin{array}{l}\text { Whether disability } \\
\text { or ill health impedes } \\
\text { ability to work in } \\
1972 \text { and before }\end{array}$ & $0.15016 \quad(11.91)$ & $0.15100(11.98)$ & $0.15136(12.01)$ & $0.15240(12.08)$ \\
\hline $\begin{array}{l}\text { Disability } x \\
1 /(66-\text { Age })\end{array}$ & -0.30160 & $-0.30376(4.75)$ & $-0.30266(-4.73)$ & $-0.29814(-4.65)$ \\
\hline \multicolumn{5}{|c|}{${ }^{a}$ t-statistics in parentheses } \\
\hline \multicolumn{5}{|c|}{ Each estimation also controls for years of schooling and age, as shown in Table 2.} \\
\hline
\end{tabular}




\begin{tabular}{|c|c|c|c|}
\hline & $\begin{array}{l}\text { No measure of earnings } \\
\text { growth included }\end{array}$ & \multicolumn{2}{|c|}{ Adding a simple measure of earnings growth... } \\
\hline Explanatory Variables & & in constant dollars & in nominal dollars \\
\hline $\begin{array}{l}\text { Average earnings, 1963- } \\
1972\end{array}$ & $-1.71 \times 10^{6}(3.92)$ & $-9.48 \times 10^{7}(1.99)$ & $-3.63 \times 10^{7}(0.66)$ \\
\hline $\begin{array}{l}\text { Earnings in 1972- } \\
\text { Earnings in } 1963\end{array}$ & & $-1.98 \times 10^{6}(3.98)$ & $-1.82 \times 10^{6}(4.06)$ \\
\hline $\begin{array}{l}\text { Schooling (Schooling } \\
\text { effects are measured } \\
\text { relative to four or more } \\
\text { years of college) }\end{array}$ & & & \\
\hline $0-8$ years & $0.04948(6.87)$ & $0.04940(6.86)$ & $0.04948(6.87)$ \\
\hline $9-11$ years & $0.05736(7.71)$ & $0.05642(7.58)$ & $0.05657(7.61)$ \\
\hline High school graduation & $0.02862(4.77)$ & $0.02799(4.66)$ & $0.02817(4.70)$ \\
\hline $1-3$ years of college & $0.04962(5.57)$ & $0.04907(5.51)$ & $0.04924(5.53)$ \\
\hline $\begin{array}{l}\text { Age in } 1973, \text { measured } \\
\text { as } 1 /(66-\text { Age })\end{array}$ & $0.61001(20.69)$ & $0.58736(19.57)$ & $0.58650(19.53)$ \\
\hline Adjusted $\mathrm{R}^{2}$ & 0.1248 & 0.1262 & 0.1262 \\
\hline
\end{tabular}


Table 5: What happens to income's effect when we measure it at an earlier age? ${ }^{\text {a }}$

\begin{tabular}{|c|c|}
\hline Explanatory variables & $\begin{array}{l}\text { 35-44 in 1973; } \\
\text { Earnings measured in 1963, when } \\
\text { individuals in sample were 25-34 }\end{array}$ \\
\hline Earnings measured in 1963 & $2.29 \times 10^{7}(0.30)$ \\
\hline \multicolumn{2}{|c|}{$\begin{array}{l}\text { Schooling (Schooling effects are measured relative to } \\
\text { four or more years of college) }\end{array}$} \\
\hline $0-8$ years & $0.02950(2.76)$ \\
\hline $9-11$ years & $0.02055(2.03)$ \\
\hline High school graduation & $0.00671(0.83)$ \\
\hline $1-3$ years of college & $0.03072(3.02)$ \\
\hline Age in 1973 , measured as $1 /(66-$ Age $)$ & $0.37579(1.56)$ \\
\hline Adjusted $\mathrm{R}^{2}$ & 0.0333 \\
\hline \multicolumn{2}{|c|}{ Replacing earnings with a simple measure of earnings growth } \\
\hline Earnings in 1966 - Earnings in 1963 & $-1.83 \times 10^{6}(2.47)$ \\
\hline \multicolumn{2}{|l|}{ Schooling } \\
\hline $0-8$ years & $0.02541(2.45)$ \\
\hline $9-11$ years & $0.01657(1.66)$ \\
\hline High school graduation & $0.00331(0.41)$ \\
\hline $1-3$ years of college & $0.02825(2.78)$ \\
\hline Age in 1973 , measured as $1 /(66$-Age $)$ & $0.58439(3.17)$ \\
\hline Adjusted $\mathrm{R}^{2}$ & 0.0349 \\
\hline Number of observations & 3489 \\
\hline
\end{tabular}

